\title{
Am/Cm Canister Temperature Evaluation in CIM5
}

by

M. A. Baich

Westinghouse Savannah River Company

Savannah River Site

Aiken, South Carolina 29808

D. C. Witt

\section{RECEIVEC \\ MAR 132000 \\ OSTI}

DOE Contract No. DE-AC09-96SR18500

This paper was prepared in connection with work done under the above contract number with the U. S. Department of Energy. By acceptance of this paper, the publisher and/or recipient acknowledges the U. S. Government's right to retain a nonexclusive, royalty-free license in and to any copyright covering this paper, along with the right to reproduce and to authorize others to reproduce all or part of the copyrighted paper. 
WESTINGHOUSE SAVANNAH RIVER COMPANY WSRC-TR-2000-00008TL SAVANNAH RIVER TECHNOLOGY CENTER

Date: $1 / 17 / 2000$

TO: W. H. MARTIN, 730-2B

FROM: L. F. LANDQN

\section{AM/CM CANISTER TEMPERATURE EVALUATION IN CIM5}

The attached document summarizes the results from two CIM5 runs during which glass was poured into stainless steel canisters that were configured with thermocouples to measure the external canister surface temperatures at elevations of 0.50 -inch, 3.5 -inch and 6.5 -inch from the canister bottom. Please refer any questions you may have regarding the contents of this document to $M$. A. Baich (Ext. 7-7692) or D. C. Witt, (Ext. 7-7754)

\section{DISTRIBUTION}

J. T. Dahlstrom, 730-1B

A. W. Bowers, 704-10F

A. P. Giordano, 730-1B

A. P. Fellinger, 730-1B

N. H. Harkey, 730-1B

D. C. Witt, 704-1T

M. A. Baich, 704-1T

STI 703-43A (4) 
WSRC-TR-2000-00008, Revision 0

\section{AM/CM CANISTER TEMPERATURE EVALUATION IN CIM5 (U)}

M. A. Baich

D. C. Witt

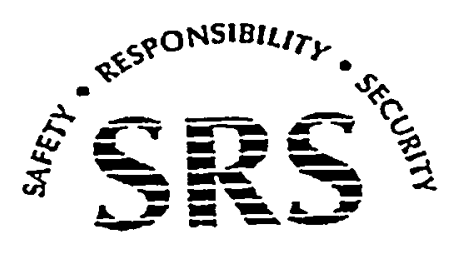




\section{DISCLAIMER}

This report was prepared gs an account of work sponsored by an agency of the United States Government. Neither the United States Government nor any agency thereof, nor any of their employees, makes any warranty, express or implied, or assumes any legal liability or responsibility for the accuracy, completeness, or usefulness of any information, apparatus, product or process disclosed, or represents that its use would not infringe privately owned rights. Reference herein to any specific commercial product, process or service by trade name, trademark, manufacturer, or otherwise does not necessarily constitute or imply its endorsement, recommendation, or favoring by the United States Government or any agency thereof. The views and opinions of authors expressed herein do not necessarily state or reflect those of the United States Government or any agency thereof.

This report has been reproduced directly from the best available copy.

Available for sale to the public, in paper, from: U.S. Department of Commerce, National Technical Information Service, 5285 Port Royal Road, Springfield, VA 22161, phone: (800) 553-6847

fax: (703) 605-6900

email: orders@ntis.fedworld.gov

online ordering: http://www.ntis.gov/ordering.htm

Available electronically at http://www.doe.gov/bridge

Available for a processing fee to U.S. Department of Energy and its contractors, in paper, from: U.S. Department of Energy, Office of Scientific and Technical Information, P.O. Box 62, Oak Ridge, TN 37831-0062, phone: (865) 576-8401

fax: (865) 576-5728

email: reports@adonis.osti.gov 


\section{DISCLAIMER}

Portions of this document may be illegible in electronic image products. Images are produced from the best available original document. 
WSRC-TR-2000-00008, Revision 0

Keywords: Canister, CIM5,

$\mathrm{Am} / \mathrm{Cm}$, Temperature

Retention: Permanent

\title{
AM/CM CANISTER TEMPERATURE EVALUATION IN CIM5 (U)
}

\author{
M. A. Baich \\ D. C. Witt
}

Publication Date: January 19, 2000

Westinghouse Savannah River Company

Savannah River Site

Aiken, SC 29808

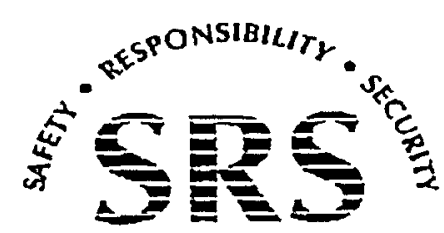

PREPARED FOR THE U.S. DEPARTMENT OF ENERGY UNDER CONTRACT NO. DE-AC09-96SR18500 


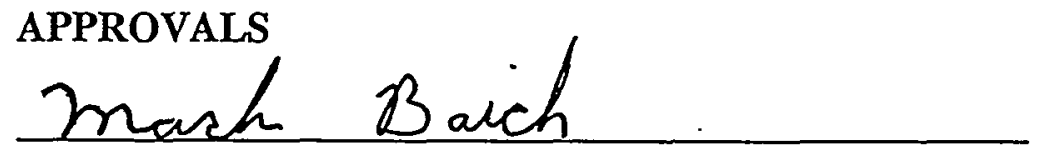

M. A. Baich, Author

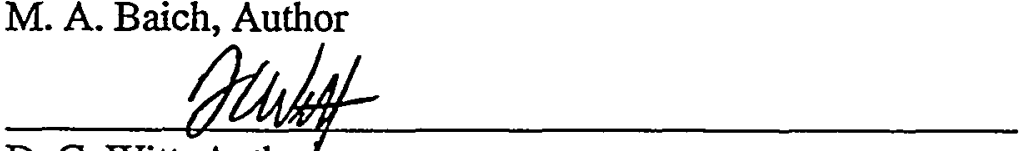

D. C. Witt, Author Misithy m. Sous

T. M. Jones, Technical Reviewer

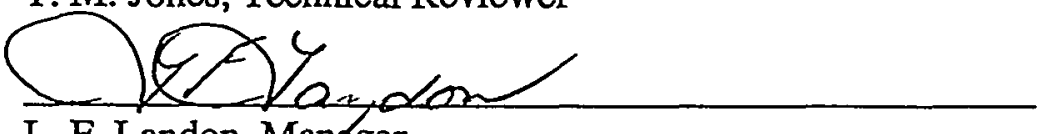

L. F. Landon, Manager $\frac{1 / 11 / 00}{\text { Date }}$

$\frac{1 / 11 / 100}{\text { Date }}$

$1 / 10 / 00$

Date

$\frac{1 / 17 / 00}{\text { Date }}$ 


\section{TABLE OF CONTENTS}

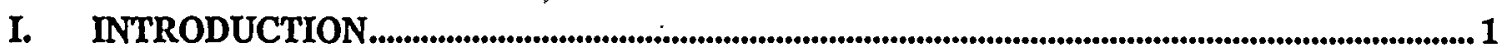

II. - SUMMARY

III. DETAILS - Canister Temperature Profiles................................................................................... 1

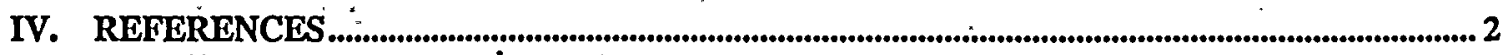


WSRC-TR-2000-00008

Page 1 of 8

\section{INTRODUCTION}

To facilitate the evaluation of alternate canister designs, 2 canisters were outfitted with thermocouples at elevations of $1 / 2,31 / 2$, and $61 / 2$ inches from the canister bottom - see Figure 1. The canisters were fabricated from two inch diameter schedule 10 and two inch diameter schedule 40 stainless steel pipe. Each canister was filled with $\sim 2$ kilograms of 49.wt\% lanthanide $(\mathrm{Ln})$ loaded 25SrABS glass during 5 inch Cylindrical Induction Melter (CIM5) runs for TTR Tasks 3.03 and 4.03. Melter temperature, total mass of glass poured, and the glass pour rates were almost identical in both runs. The schedule 40 canister has a slightly smaller $\mathrm{D}$ compared to the schedule 10 canister and therefore filled to a level of 9.5 inches compared to 8.0 inches for the schedule 40 canister. The schedule 40 canister had an empty mass of 1906 grams compared to 919 grams for the schedule 10 canister.

\section{SUMMARY}

The schedule 10 canister was found to have a higher maximum surface temperature by about $50-100{ }^{\circ} \mathrm{C}$ (depending on height) during the glass pour compared to the schedule 40 canister. The additional thermal mass of the schedule 40 canister accounts for this difference. Once filled with glass: each of the canisters cooled at about the same rate, taking about an hour to cool below a maximum surface temperature of $200^{\circ} \mathrm{C}$. No significant deformation of the either of the canisters was visually observed.

\section{DETAILS - Canister Temperature Profiles}

Two CIM5 runs were made to produce a 49 wt\% Ln loaded 25SrABS glass.

Figure 2 presents a 5 -second average pour rate for each of the two pours. Variations in either pour rate or mass of glass poured are minor. Figures 3 and 4 present the temperature profiles for the schedule 10 and schedule 40 canisters, respectively during the pour. Each of the temperature profiles demonstrated the same basic character: slowly increasing temperature as the glass already poured radiated heat up the canister wall, rapid temperature increase as the glass level reached the level of the thermocouple, and a slow decline as heat was being lost by convection to the outside air.

The schedule 40 canister temperature response was slowed by the larger thermal mass of the canister wall. The increased thermal mass led to a lower maximum temperature of 50-100 ${ }^{\circ} \mathrm{C}$ depending upon the vertical location. Figures 5 and 6 demonstrate the difference. However, once filled with glass the time to cool below 200 deg $C$ was about the same for both canisters. 
WSRC-TR-2000-00008

Page 2 of 8

\section{REFERENCES}

1. WSRC-NB-99-00173, CIM5 Laboratory Notebook

2. T. M. Jones and D. C. Witt, CIM5 TTR Task 4.02,4.03-Coil Voltage and Insulation Sleeve Temperature Measurement (U), SRT-AMC-99-0213, November 2, 1999.

3. T. M. Jones and D. C. Witt, CIM5 TTR Task 3.03-Interlock Recovery During Drying Phase (U), SRT-AMC-99-0214, November 3, 1999. 
Figure 1 Instrumented $\mathrm{Am} / \mathrm{Cm}$ Canisters

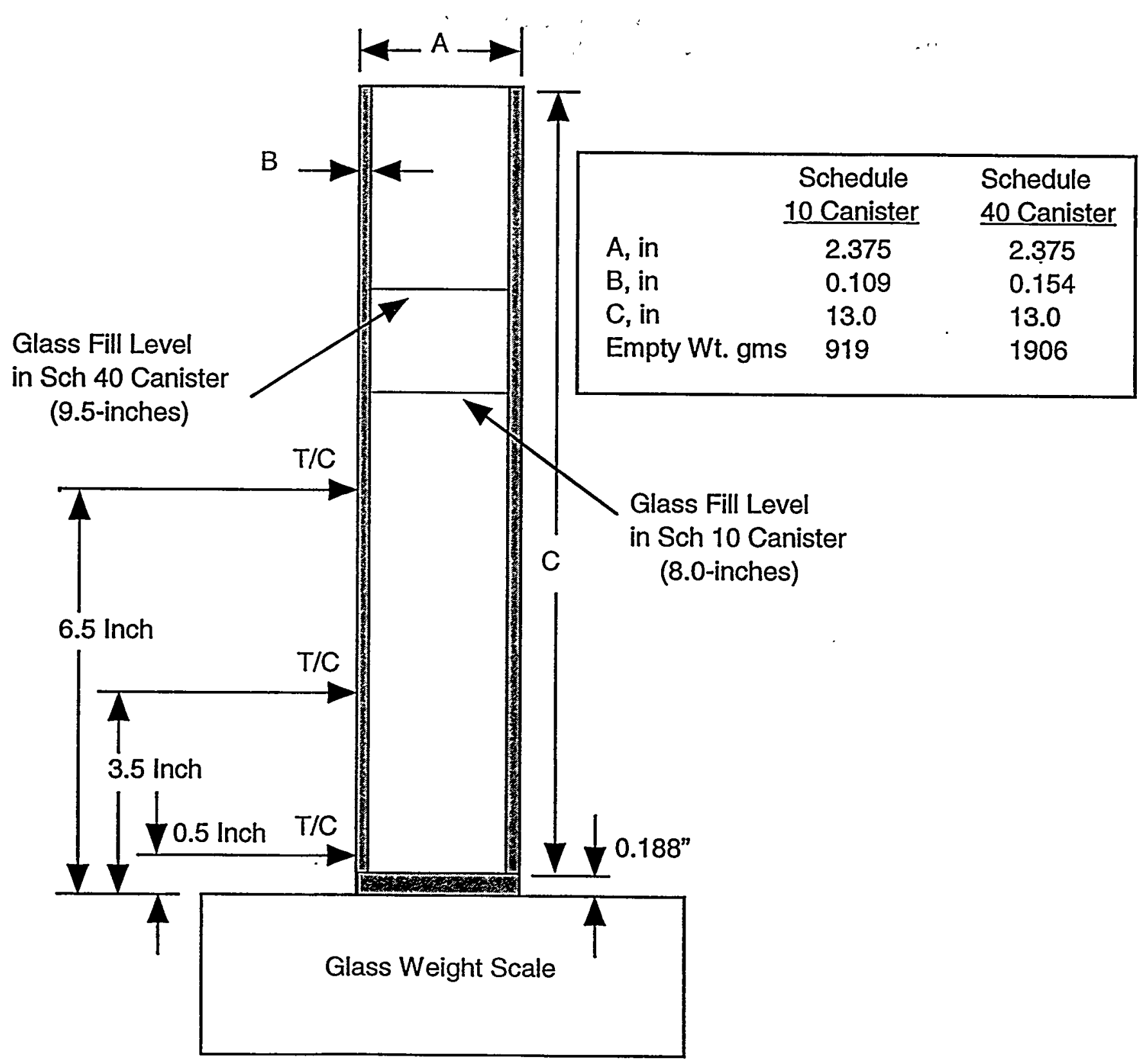


Figure 2 Five Second Average Pour Rate

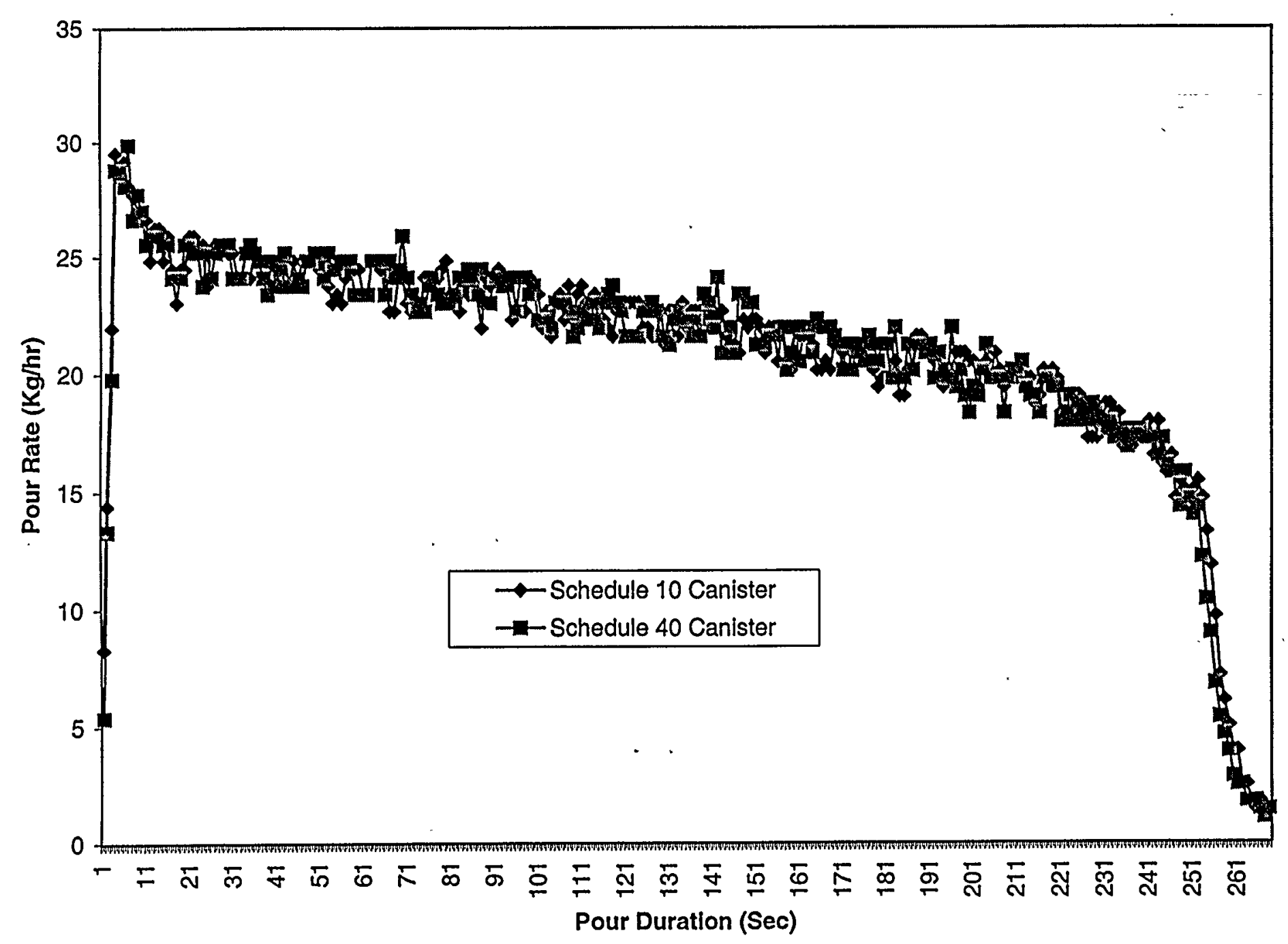


Figure 3 Schedule 10 Canister Temperature Profile

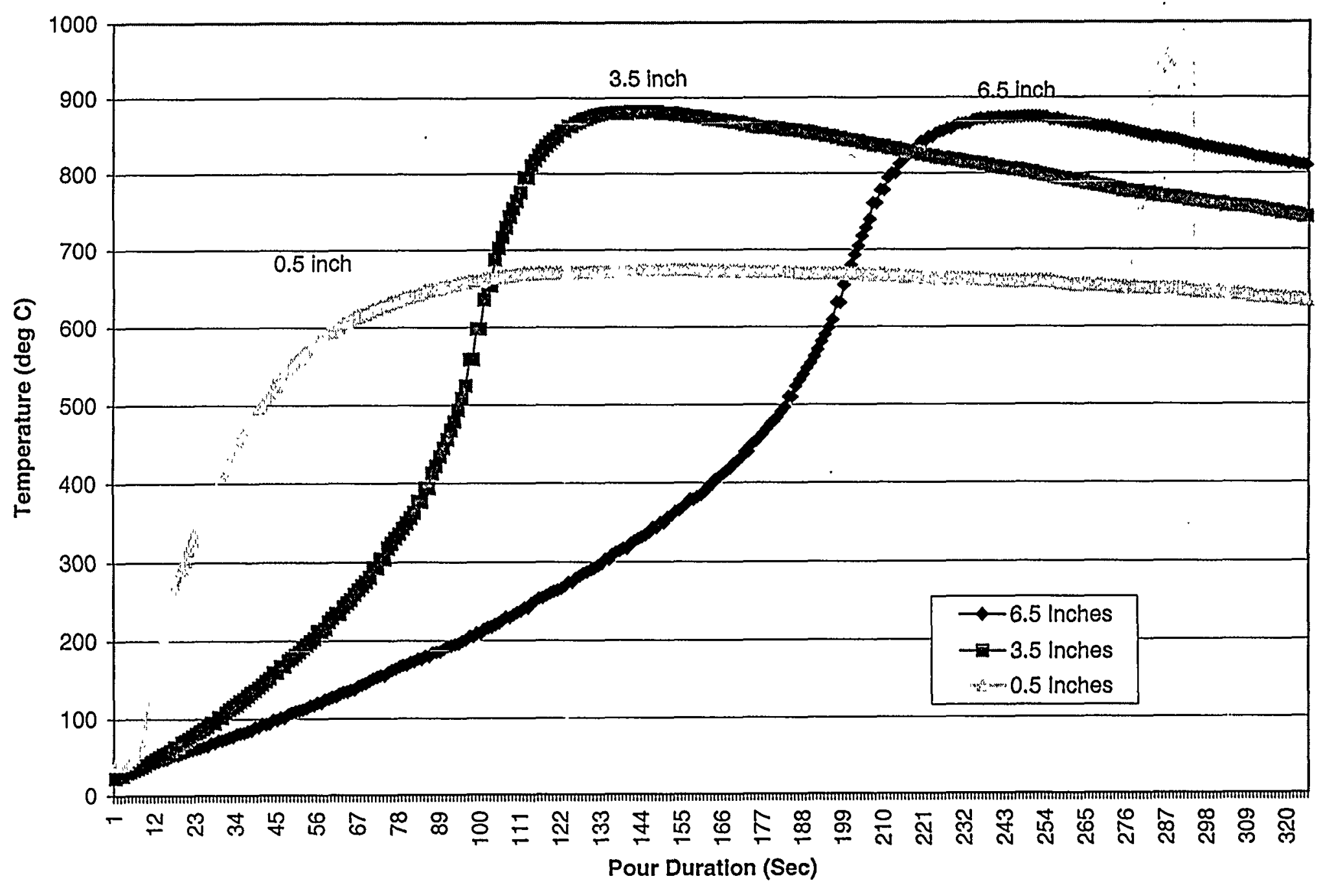


Figure 4 Schedule 40 Canister Temperature Profile

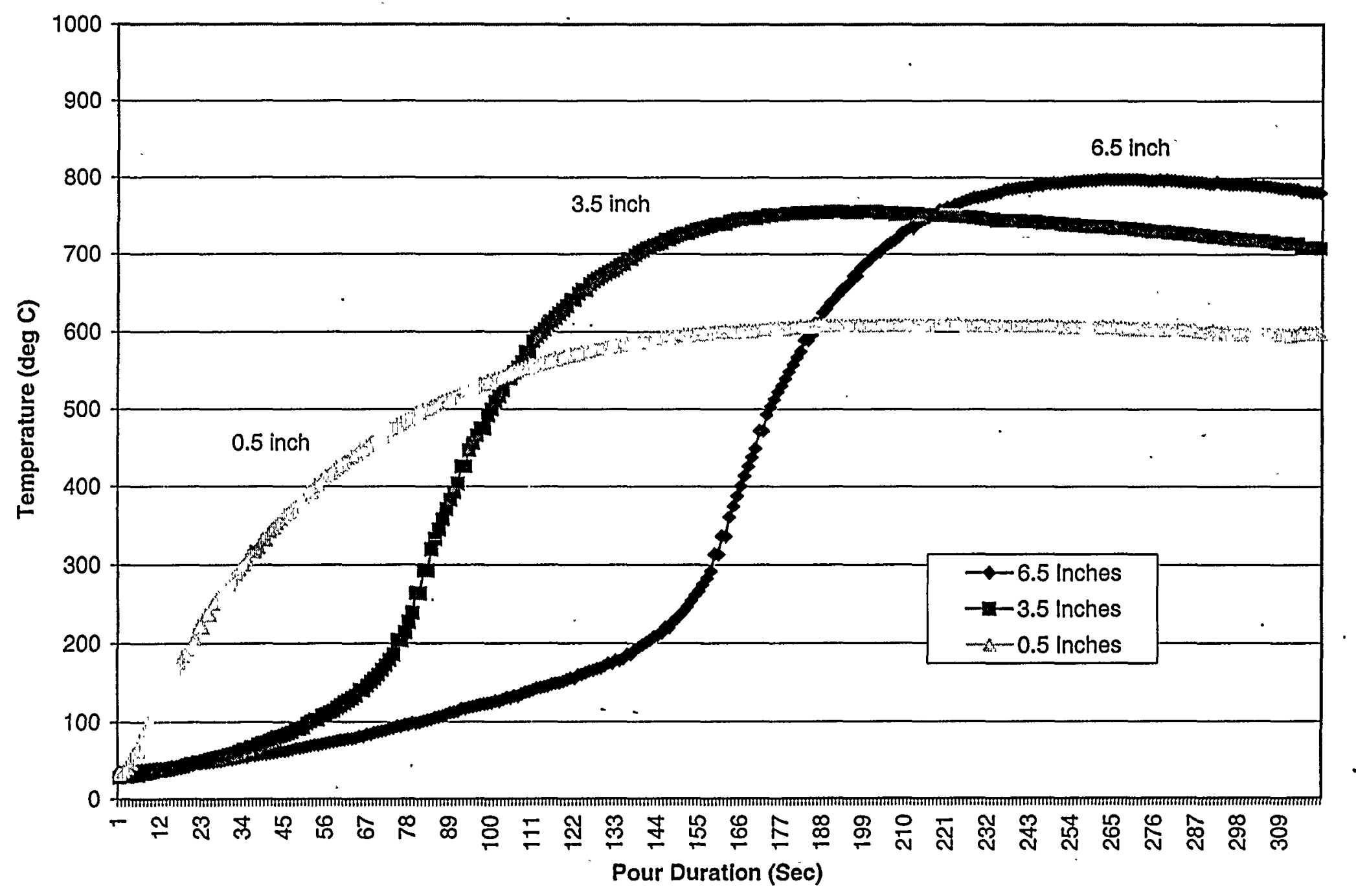


Figure 5 Schedule 10 Canister Cool Down

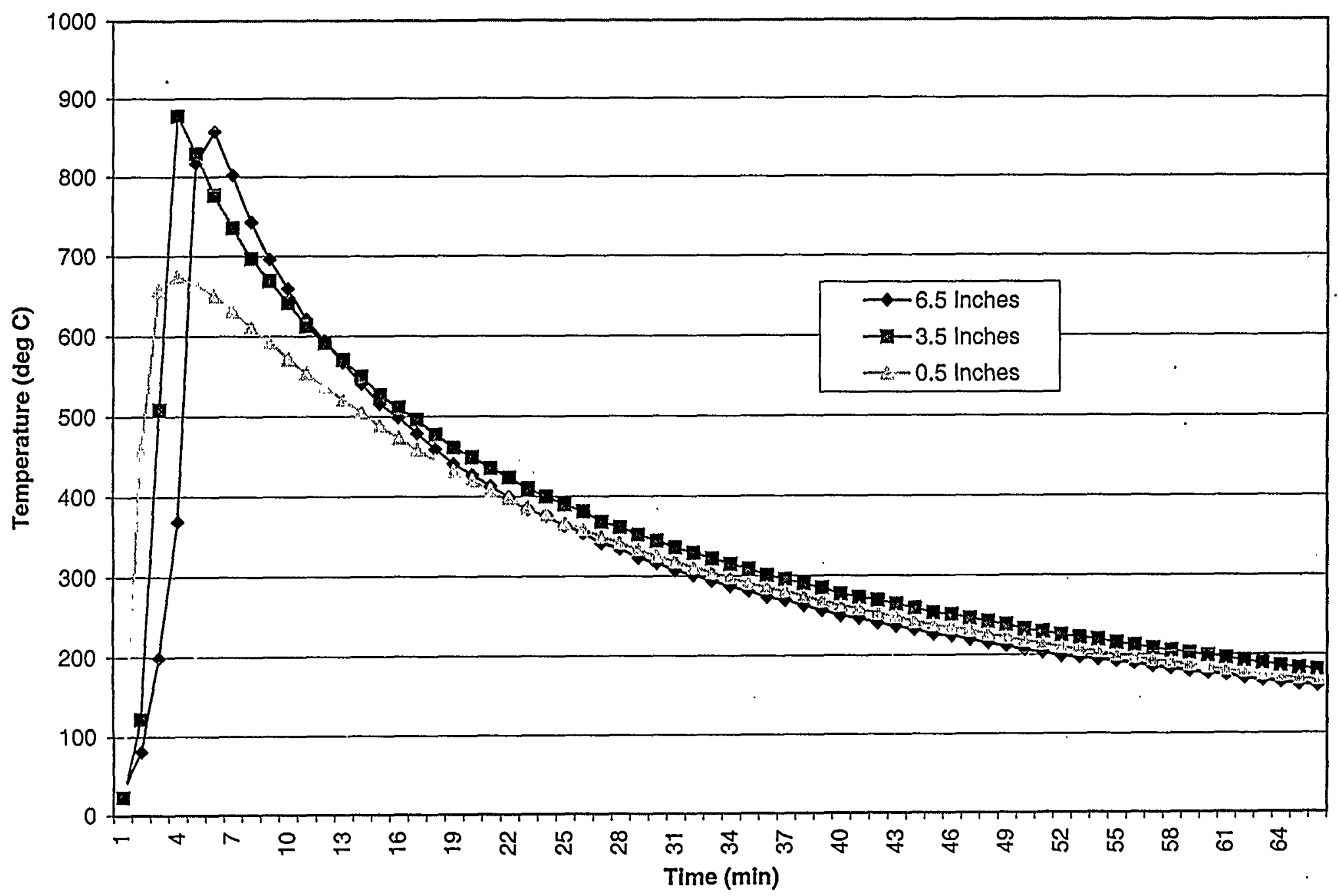


Figure 6 Schedule 40 Canister Cool Down

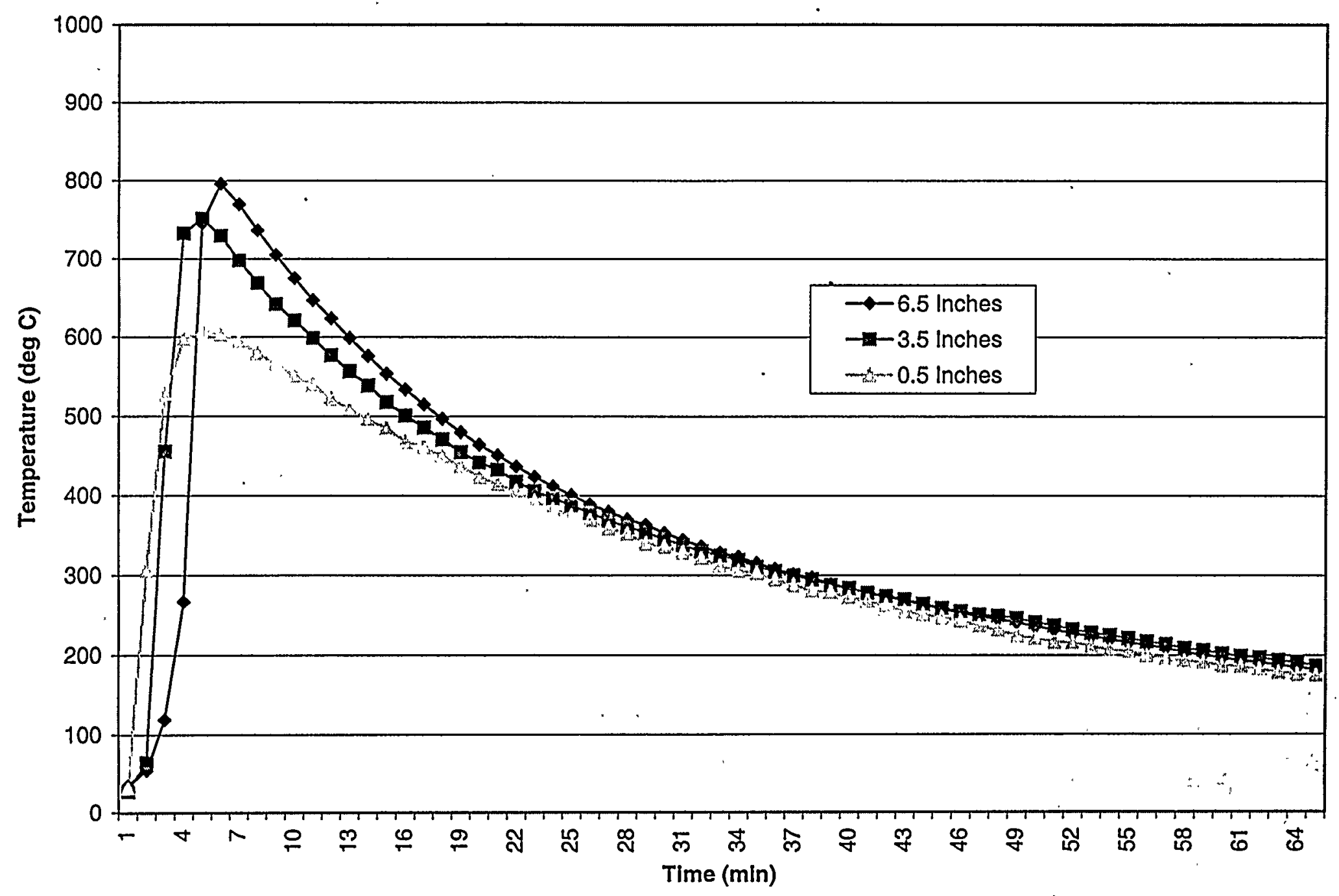




\section{DISTRIBUTION:}

L. M. Papouchado, 773-A

E. W. Holtzscheiter, 773-A

L. F. Landon, 704-1T

M. A. Baich, 704-1T

D. C. Witt, 704-1T

T. M. Jones, 704-1T

D. H. Miller, 704-1T.

M. E. Stone, 704-1T

T. K. Snyder, 704-T

D. K. Peeler, 773-43A

C. B. Miller, 773-A Am/Cm File, 704-1T

STI, 703-43A (4) 